\title{
The Lending Service Library
}

$I^{\mathrm{N}}$ JANUARY 1940 an experimental rental 1 library was opened at Columbia University as a component part of the university libraries. After almost six years of operation this library stands out as one of the most popular and useful services ever offered at the university and is now one of the show places on the campus. While many college and university libraries have maintained small rental collections or duplicate pay shelves, no library has offered such a service on so wide a scale or so effectively as Columbia. An examination of the methods employed there may be of value to other libraries.

The problem of providing the most recent titles in great enough quantity and quickly enough to satisfy the readers' wishes was an old one at Columbia and had been studied for some time. It was decided that the feasible solution was a rental library from which enough revenue would be derived to pay for the many duplicates needed to meet demand. The Lending Service Library was thus created to make accessible to members of the university community the latest books on all nontechnical subjects and to offer as many of these books as possible for circulation on the day of publication. As a recompense for this service a rental fee of four cents a day with a sixteen-cent minimum charge was asked of borrowers. The subsequent success of the service resulted in a modification of rates to three cents a day with a ten-cent minimum.

One large corner room conveniently lo-

Note: Mr. Estes was formerly in charge of lending service in the Columbia University Libraries. cated in South Hall, the main university library, was set aside for this service. The room contained shelving space for approximately four thousand volumes, and, although the space had not been planned for this purpose, an arrangement of charging desk, catalog, and display cases near the entrance divided work space from the reading room. Three reading tables, lamps, and a number of desks of the type used for carrell study were placed in the center of the floor and along the walls, giving the room an air of brightness and informality.

When the library was first copened, the problem arose as to whom books could be rented. Commercial rental libraries in the neighborhood raised the point that they could not meet such competition as Columbia would offer if our doors were opened to all who lived in the community. Therefore, service was restricted to the faculty, students, staff, including the custodial workers, alumni, government employees located in the research laboratories of the university, and special permit borrowers. In the first six months 1642 readers had registered. Of these over 1200 were students. In December 1945 approximately 3000 active borrowers were listed and thousands of inactive ones. The inactive file consists of the registration cards of those readers who have not withdrawn books in the past six months. When registering, the new borrower shows a bursar's receipt or proper campus identification and then fills out a slip, giving name, address, and school of study. This information is first tabulated, then typed on a manila card. The card is filed at the 
charging desk as an identification record. No books are charged until identification is checked.

Upon the opening of the Lending Service Library, a postal card with a printed message describing the service and the fees was mailed to the entire student body, the faculty, and the staff. Ever since then publicity of some sort has been employed to keep before the readers the idea of the service. Colored posters have been placed on the university bulletin boards, and each week a mimeographed list of new accessions, "Books You Want to Read," is sent out to all libraries for posting and is mailed to those borrowers who are interested. Within the Lending Service Library, posters, newspaper clippings, reviews of recent acquisitions, pictures of authors in the news, and best seller lists are displayed each week to stimulate interest in reading.

The most important problem involved in the directing of the Lending Service $\mathrm{Li}$ brary is that of book selection and book buying. Since one of the primary purposes of the collection is to provide books as they are published, a majority of the titles are ordered by the day of publication. The librarian must study every publisher's list and all prepublication advertising and reviews in order to judge as carefully as possible the merits of each forthcoming title. Visits to bookstores and to jobbers are helpful in determining buying lists. The Columbia University Bookstore has cooperated with the library, making it possible to see all advance copies of books received.

\section{Ordering the Books}

Book orders are telephoned almost daily to the bookstore through which most of the stock is purchased. Generally one title of a book is ordered first and duplicates are requested only after the demand for the book has been established. If the title is a heavily advertised piece of fiction like Remarque's Arch of Triumph, one can be reasonably sure that twenty copies will be needed on publication day and order accordingly. However, the vagaries of the public's taste and misleading advertising have led us to err on the side of caution. As more copies can generally be obtained on a day's notice, it has been proved a wise policy to buy with caution. Some welladvertised titles do not live up to expectations and the books are soon left standing on the shelves while other titles not pushed so freely in advance by the publishers may be catapulted into immediate success. When Strange Fruit appeared, only two copies were ordered but subsequent demand led to the purchase of eighteen more copies. Only one copy of most mystery stories is bought, as it has been found that the mystery audience is avid but small and duplicates are a poor investment.

Nonfiction is more difficult to choose than either straight fiction or mystery stories. Its popularity is more variable and dependent upon many factors rather than upon the best seller lists which affect the reading of fiction to a great extent. In choosing nonfiction one or two copies of a book have generally been found to be sufficient, although some titles outstrip fiction in popularity. For instance, fifteen copies of Teacher in America were needed, but, on the whole, the need for duplication is not great and can be judged fairly accurately.

Orders for some books are placed well in advance of publication so that most books are delivered before or on the day of publication. Since orders are sent out directly from lending service, invoices are checked there on the arrival of the books and then sent to the acquisitions department where bills are paid and final records filed. New stock is examined to make sure no defective 
material is present and then the books are stamped, wrapped in cellophane to preserve the dust jackets, and made available for circulation. These operations are performed immediately upon the receipt of the books, and the new stock reaches the public on the day it arrives in the library. Books arriving before publication day are held until the release date set by the publishers.

The cataloging of the books is handled in as simple a manner as possible. When books are ordered, two order cards are typed, one for the acquisition department and one for lending service, where the order card eventually becomes the shelflist card. On the order card appears the name of the author, title, publisher, date, and price, as well as the date ordered and the firm with whom the order is placed. As soon as a new title is ordered, the order card for lending service becomes a work card. An assistant checks it against the union catalog and the L. C. catalog to determine the main entry, the author's correct name, and dates. A simple catalog card is then typed, giving the information on the work card and the tracing which usually consists of only a title. No subject headings are used except for biography. Upon the arrival of the books, the main entry cards are sent to the cataloging department where the necessary duplicates are typed and filed in the union catalog. The original author cards are returned to lending service and they are filed with title cards in the lending service cata$\log$.

\section{Discarding}

The discarding of books is equally as important as the adding of new material. Several times a year the shelves are examined and all books that have not circulated during the past six months are segregated for sale. At regular intervals sale lists are prepared and sent to all libraries in the university where the lists are checked. The lending service ordinarily supplies most of the fiction titles for the general library. Usually departmental libraries buy about half of the titles listed. These books are then transferred through the acquisitions department which in turn credits lending service with the money involved. Books which are not sold to the libraries are then placed on a sale shelf for the public. The prices of books so disposed of vary in accordance with the original price of the book, the physical condition of the book, and the type of the book. The standard price for secondhand fiction is seventy-five cents while nonfiction sells for one dollar or more.

The sale of books is more or less a continuous process since new sale books are added at frequent intervals. If books do not sell promptly, then their price is reduced. In the past all used books have been sold, so that the problem of excess material has never arisen. No binding of worn books is done. If a book circulates so often that the binding breaks, a duplicate copy is purchased and the worn one sold. This policy is adhered to for two reasons: first, a rebound book is difficult to rent and to sell; and second, the attractive appearance of the room, one of the most important factors in its success, would be injured by shelving rebound material.

Methods employed at the circulation desk are as direct and practical as possible. A book card is made for each copy of a title or volume and filed alphabetically by author in the charging tray. These cards are divided into two groups, the in-file and. the out-file. As soon as a book is brought to the desk to be charged, the proper card from the in-file is withdrawn, dated, and the borrower's name written on it. During the course of the day, the circulation figures are determined by counting these cards which are then filed in the out-file. When a book 
is returned, the reverse process is performed, the number of days the book has been in circulation is computed and the charge made accordingly. Receipts from each book are recorded in a receipt book and the sum taken in is tallied with the amount in the cash drawer.

\section{Subjects of Interest}

The readers at Columbia have shown themselves interested in the widest variety of subjects. Serious fiction attracts the greatest number of readers and rents more steadily than books in any other field. For instance, Hemingway's For Whom the Bell Tolls was so popular that forty copies were purchased. Furthermore, the popularity of a solid title endures. One copy of The Heart Is a Lonely Hunter still rents although it is now more than five years old. A new novel frequently revives interest in other titles by the same author. Although the general policy is to purchase only current books, the demand for earlier stories by Katherine Anne Porter when The Leaning Tower appeared caused us to add her other titles. The success of Marquand's play, The Late George Apley, caused a similar demand for the novel.

In the field of nonfiction, books relating to international affairs are perhaps the most widely read. The many recent titles on Russia and China, postwar planning, solving the riddle of peace, have all been in constant demand. However, war books have failed to rent well except for a few outstanding titles such as Ernie Pyle's Brave $M e n$ and Bill Mauldin's Up Front. However, most of the reports from journalists on distant fronts do not arouse appreciable interest. Recent books on popular psychiatry are widely read. All studies of Freud, both biographical and critical, and books by Horney, Zilboorg, and others are equally in demand. Biography is variable, certain titles catching the readers' attention and others seemingly as well written, being overlooked. Historical biography is followed by only a small audience. The poetry of W. H. Auden, Marianne Moore, and Karl Shapiro and books of literary criticism are constant renters. Plays popular on Broadway rent well, others do not. Art books which have sufficient text are excellent for display purposes and will rent fairly well. Virtually no technical books except photography guides are purchased. Scientific works are seldom requested.

\section{Supply of Books}

At present approximately 2500 books are in use in this room, about half of which are nonfiction. During the winter months about I50 new volumes are added each month, though considerably fewer are bought during the summer when publishing is not so active. The demand for the rental service has grown steadily since its beginning except for a slight decline in the war years. Members of the faculty and students now rely upon this collection for study as well as for leisure-time reading.

The financial success of the service has been outstanding. For the past three years the income from the rental and sale of books has paid for all books and all salaries. The department has cost the university only a few hundred dollars a year for supplies. It is possible that in the future all expenses may be covered. Lending service has in no way interfered or competed with the work done in the other university libraries. Their work goes on just as in the past, but the rental service has made it possible for any campus reader to consult the latest books on their immediate release. The Lending Service Library is more than a unique idea; it is the practical answer to the university librarian's problem of meeting popular demand with supply. 